\title{
L-Acetylcarnitine: A Mechanistically Distinctive and Potentially Rapid-Acting Antidepressant Drug
}

\author{
Santina Chiechio ${ }^{1}$, Pier Luigi Canonico ${ }^{2}$ and Mariagrazia Grilli ${ }^{3, *}$ \\ 1 Department of Drug Sciences, Section of Pharmacology and Toxicology, University of Catania, \\ 95125 Catania, Italy; chiechio@unict.it \\ 2 Department of Pharmaceutical Sciences, University of Piemonte Orientale, 28100 Novara, Italy; \\ pierluigi.canonico@uniupo.it \\ 3 Laboratory of Neuroplasticity, Department of Pharmaceutical Sciences, University of Piemonte Orientale, \\ 28100 Novara, Italy \\ * Correspondence: mariagrazia.grilli@uniupo.it; Tel.: +39-0321-375-828
}

Received: 30 October 2017; Accepted: 18 December 2017; Published: 21 December 2017

\begin{abstract}
Current therapy of mood disorders has several limitations. Although a high number of drugs are clinically available, as of today, nearly two-thirds of individuals do not achieve full symptomatic remission after treatment with conventional antidepressants. Moreover, several weeks of drug treatment are usually required to obtain clinical effects, a limitation that has considerable clinical implications, ranging from high suicide risk to reduced compliance. The characteristic lag time in classical antidepressant effectiveness has given great impulse to the search for novel therapeutics with more rapid effects. L-acetylcarnitine (LAC), a small molecule of growing interest for its pharmacological properties, is currently marketed for treatment of neuropathic pain. Recent preclinical and clinical data suggested that LAC may exert antidepressant effects with a more rapid onset than conventional drugs. Herein, we review data supporting LAC antidepressant activity and its distinctive mechanisms of action compared with monoaminergic antidepressants. Furthermore, we discuss the unique pharmacological properties of LAC that allow us to look at this molecule as representative of next generation antidepressants with a safe profile.
\end{abstract}

Keywords: L-acetylcarnitine; mood disorders; antidepressant; chronic pain; acetylation; epigenetics; adult neurogenesis; NF-kB; mGlu2

\section{Introduction}

L-Acetylcarnitine (LAC) is a small molecule of growing interest for its biological and pharmacological properties. Originally, LAC primary function was attributed to its role in the transport of short- and medium-chain acyl groups outside mitochondria, a step required for utilization of fatty acids and glucose [1]. Besides its role in energy metabolism, during the last two decades, a number of studies have shown that LAC actions range from antioxidant, neuromodulatory, and neuroprotective effects to modulation of gene expression [2-8]. Because of the multiplicity of actions and the excellent safety and tolerability profile, LAC efficacy has been investigated in a number of clinical conditions and neurological disorders (Table 1). The drug is currently marketed for the treatment of neuropathic pain. Recent preclinical and clinical data support LAC antidepressant effects and suggest novel underlying cellular and molecular effects, including epigenetic mechanisms. Herein, we discuss the unique pharmacological properties of LAC that allow us to consider this molecule as a novel antidepressant molecule. 
Table 1. L-Acetylcarnitine (LAC) clinical studies for disorders of central and peripheral nervous system.

\begin{tabular}{cc}
\hline Clinical Condition & References \\
\hline Alzheimer's disease & {$[9-12]$} \\
Parkinson's disease & {$[13]$} \\
Huntington's disease & {$[14]$} \\
Down's syndrome & {$[15]$} \\
Dysthymic/Depressive disorder & {$[16,17]$} \\
Diabetic neuropathy & {$[18-21]$} \\
HIV Neuropathy & {$[22]$} \\
Carpal tunnel syndrome & {$[23]$} \\
Fibromyalgia & {$[24,25]$} \\
\hline
\end{tabular}

\section{Role of Endogenous LAC in Energy Metabolism}

LAC is an endogenous compound widely distributed in many tissues, including brain. Chemically, LAC is the acetylated derivative of the amino acid L-carnitine whose function is generally correlated with regulation of energy metabolism within mitochondria [1]. Its de novo synthesis is catalyzed by the enzyme carnitine acetyltransferase (CAT), mainly located on the inner mitochondrial membrane as well as in endoplasmic reticulum and peroxisome [26,27]. CAT promotes the transfer of an acetyl group from acetyl-Coenzyme A (acetyl-CoA) to carnitine, thereby producing LAC and free CoA (Figure 1) [28,29].<smiles>C[N+](C)(C)C[C@H](O)CC(=O)O</smiles>

L-carnitine
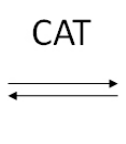<smiles>CC(=O)O[C@@H](CC(=O)O)C[N+](C)(C)C</smiles>

L-acetylcarnitine

Figure 1. Biosynthesis of L-Acetylcarnitine. The acyl moiety is transferred from acetyl-CoA to the hydroxyl group of carnitine by the enzyme carnitine acetyltransferase (CAT).

After being synthetized, LAC is transported outside mitochondria into the cytosol by the enzyme carnitine/acetylcarnitine translocase (CACT) [30-32]. This is a crucial metabolic reaction for $\beta$-oxidation of fatty acids whereby LAC facilitates the transport of acetyl-CoA across mitochondrial membranes [1]. A nuclear carnitine acetyltransferase can also convey LAC from cytosol to the nucleus, increasing the local pool of available acetyl groups [33]. It has been estimated that neurons from adult brain contain a relatively high level of LAC, with highest content in hypothalamus $[34,35]$.

\section{Pleiotropic Effects and Mechanisms for Exogenously Administered LAC}

When exogenously administered, LAC is easily absorbed. Due to its amphiphilic structure, LAC is mobile throughout the plasma membranes and can rapidly cross blood-brain barrier [36,37]. Indeed, LAC can be transported by the high-affinity sodium-dependent organic cation/transporter (OCTN2), which is functionally expressed in cells forming the blood-brain barrier [38].

A wide range of mechanisms have been proposed to explain the multiplicity of LAC activities within nervous tissues. In particular, it has been demonstrated that LAC modulates the activity of nerve growth factor (NGF) and enhances the expression of NGF receptors in striatum/hippocampus during development and in aged rats [39-41]. Moreover, LAC modulates different neurotransmitter 
systems, including the gabaergic, dopaminergic, and cholinergic system [42-46], the latter by increasing acetyl-CoA content and choline acetyltransferase (ChAT) activity [47-49].

Recently, evidence that LAC serves as donor of acetyl groups further supported additional functions that go beyond its classical role in energy metabolism. In particular, its ability to contribute to acetylation of -OH or - $\mathrm{NH} 2$ functional groups on amino acids and N-terminal groups in proteins $[2,7,8,50,51]$ has opened up new avenues to explain mechanisms underlying important LAC activities. Indeed, LAC has been suggested to modulate gene expression by an epigenetic mechanism exerted via acetylation of histone proteins and transcription factors [7,8,50-53]. Epigenetic mechanisms are physiologically achieved by activity of two classes of enzymes-histone acetyltransferases (HATs) and histone deacetylases (HDACs) — that transfer and remove acetyl groups in histones and transcription factors, respectively [54]. HATs and HDACs were originally identified as chromatin modifying enzymes by operating posttranslational modifications of histones [55]. Later, it was demonstrated that HATs and HDACs do not exclusively target histone proteins but also modulate the activity of a number of transcription factors. Several HAT and HDAC inhibitors are currently under investigation for epigenetic modulation of gene expression. LAC itself, similarly to HDAC inhibitors, regulates epigenetic mechanisms by increasing the acetylation level of histones and transcription factors such as NF- $\mathrm{KB}[8,51,53,56]$. Studies from our groups indicated that LAC regulates the activity of NF-KB signaling pathways by increasing acetylation of the p65/RelA subunit at lysine 310, an event that may enhance transcriptional activity of the protein $[7,8]$. This effect has been correlated with the ability of LAC to induce expression of metabotropic glutamate receptor type-2 (mGlu2), a potential underlying mechanism for a wide spectrum of pharmacological activities ranging from analgesic, proneurogenic, and antidepressant effects of LAC [7,8,50,51,56,57].

\section{LAC as a Novel Antidepressant Drug with Unique Properties}

In humans, and particularly in the elderly, the beneficial effects of LAC has been reported in mood disorders, including major depressive disorder and dysthymia [58-60]. More recently, LAC was investigated in a multicentric, double-blind, randomized clinical trials (RCT) in a population of elderly patients with dysthymic disorder [16]. The drug was evaluated in comparison with fluoxetine for an observation period of seven weeks. LAC and fluoxetine resulted equivalent in their antidepressant efficacy. Of interest, a difference in latency time of clinical response was observed between the two drugs, namely one and two weeks for LAC and fluoxetine, respectively, potentially suggesting a more rapid effect elicited by LAC in humans [16]. Although the rapidity in the onset of LAC therapeutic effects needs to be confirmed in studies with larger sample sizes and in mood disorders other than dysthymia, it is quite interesting in view of the fact that rapid effects have also been observed in preclinical models of depressive-like behavior [51].

A recent meta-analysis investigated the effects of LAC on depressive symptoms across published RCT [61]. Again, LAC administration demonstrated efficacy when compared to placebo. Moreover, LAC efficacy was comparable to classical antidepressant agents, but with significantly fewer side effects [61]. These findings are in agreement with another meta-analysis including 34 studies and 4769 patients with persistent depressive disorders. In that analysis, LAC treatment showed lower rates of adverse events and discontinuation than any other drug comparator [62]. In addition, a meta-analysis confirmed that LAC was more effective in older than in younger patients [61]. At present, the reason for a better drug response in elderly people is not clear. Although additional research efforts are required to confirm these findings, the results suggest that LAC may represent a potential alternative to classical antidepressants. Moreover, these clinical observations suggest that LAC may potentially have a mechanism of action that is distinct from conventional antidepressants. Surprisingly, despite these interesting clinical findings, in the past, very few studies have attempted to investigate underlying mechanism(s) of LAC antidepressant effects.

One interesting form of neuroplasticity is adult neurogenesis, the process of generation of new neurons in adulthood. In the dentate gyrus of hippocampus adult neurogenesis occurs in humans 
across their entire life span [63]. Although reduction of adult neurogenesis per se does not result in depressive-like behavior, it has been proposed that adult hippocampal neurogenesis (ahNG) may be required for some behavioral effects of antidepressants in rodent models and potentially contribute to the antidepressant activity of these drugs in the clinical setting [64,65]. Antidepressant drugs indeed increase hippocampal neurogenesis in rodents [66-68], and an increased number of hippocampal neural progenitor cells (NPC) and granule neurons are reported in postmortem brain of depressed patients undergoing antidepressant therapy [69]. In addition, several experimental studies demonstrate that antidepressants can counteract the inhibitory effect of stress on ahNG in rodent models of depressive-like disorder [70,71].

Among regulators of ahNG the NF- $\mathrm{KB}$ family of transcription factors has been receiving attention from our and other laboratories [72-82]. In particular, we demonstrated the involvement of NF- $\mathrm{kB}$ signaling pathways in the modulation of adult hippocampal neurogenesis in vivo [72] and in the effects of several drugs that are endowed with proneurogenic and antidepressant activity both in vivo and in vitro $[78,79,82]$. A few years ago, we showed that LAC is a very potent proneurogenic molecule whose in vitro effects on neuronal differentiation of adult hippocampal neural progenitors (ahNPC) are independent of its neuroprotective activity [8]. The in vitro proneurogenic effects of LAC appear to be mediated by activation of the NF- $\mathrm{KB}$ pathway and subsequent NF- $\mathrm{KB}$-mediated upregulation of metabotropic glutamate receptor 2 (mGlu2) expression. Indeed, (i) LAC treatment of ahNPC resulted in acetylation of p65 at lys(310) and in mGlu2 protein upregulation, and (ii) LAC-induced mGlu2 expression could be abolished by interfering with NF-KB p65 nuclear translocation [8]. These results prompted us to evaluate LAC effects in vivo in adult mice. We showed that chronic LAC administration blocks depressive-like behavior caused by unpredictable chronic mild stress (UCMS) [8], a preclinical model with face validity and predictivity for human major depression. The utilized dose $(100 \mathrm{mg} / \mathrm{kg}$, i.p.) was chosen for its clinical relevance since it corresponds to the lowest recommended dose in humans $(0.5 \mathrm{~g} /$ day) [83]. Furthermore, that dose regimen effectively increased plasma levels of LAC in chronically treated mice [84]. LAC-mediated behavioral effects correlated with upregulated expression of mGlu2 (and not mGlu3) receptor in hippocampi of stressed mice [8]. Moreover, we demonstrated that chronic LAC treatment significantly increased ahNG [8]. Unlike mGlu2 effects, chronic LAC treatment correlated with increased hippocampal neurogenesis in both stressed and unstressed mice [8]. In this respect, LAC is similar to classical antidepressants that also promote neurogenesis in naive mice when chronically administered [65,66].

In the same year of our findings, a relevant paper confirmed and further extended these observations by demonstrating LAC-mediated antidepressant effects not only following chronic stress, but also in a genetic model of depression, namely Flinders Sensitive Line (FSL) rats [51]. Also in this preclinical model, LAC increased NF- $k B$ p 65 acetylation, thereby enhancing $m G l u 2$ receptor gene expression not only in hippocampus but also in prefrontal cortex [51]. LAC antidepressant effects were long lasting, being still present two weeks after drug withdrawal. On the contrary, in parallel studies, the effects of a classical tricyclic antidepressant like chlorimipramine disappeared after drug withdrawal. Even more strikingly, LAC exhibited antidepressant activity within 2-3 days following administration, compared with 14 days required by chlorimipramine [51]. Of interest, we also observed a remarkably rapid increase in the number of newly generated neurons in hippocampi of LAC-treated mice [8]. In line with Cuccurazzu's findings, Nasca and colleagues proposed that LAC promotes rapid antidepressant responses, at least in part, via epigenetic mechanisms that may involve acetylation of histone proteins and NF- $\mathrm{KB}$ p65, activating in turn $m G l u 2$ receptor and BDNF gene expression. Of note, a significant reduction of LAC in hippocampi and prefrontal cortex of FSL rats compared to Flinders Resistant Line rats was recently reported, although it was not clear whether LAC mediated antidepressant effects were linked to a correction of its deficiency in those brain regions [85].

Several critical aspects need to be highlighted and further discussed. First of all, LAC is a non-specific acetylating agent and it is unlikely that its antidepressant and proneurogenic actions are solely due to acetylation of nuclear proteins such as p65 and histones. It is possible that the 
drug acetylates other, even non-nuclear, target proteins. Further studies should be devoted to the identification of those proteins, which may potentially suggest new pharmacological targets.

It should also be underlined that the idea that NF- $\mathrm{KB}$ and p65-mediated transcriptional activation per se results in antidepressant or proneurogenic effects is challenged by opposite literature data. Chronic stress augments NF-kB-dependent transcription in the hippocampus [73] and in Nucleus Accumbens (NAc) [86]. In their elegant study, Koo and colleagues demonstrated a critical role for NF-KB signaling in the cellular and behavioral effects of stress via proinflammatory cytokines [73]. Stress was shown to activate NF- $\mathrm{kB}$ signaling and decrease neural stem cell proliferation in the adult hippocampus. Moreover depressive-like behavior induced by exposure to chronic stress appeared to be mediated by NF- $\mathrm{KB}$ signaling; i.c.v. administration of NF- $\mathrm{KB}$ signaling inhibitors resulted in antidepressant activity and prevented the negative effects of stress on hippocampal neurogenesis [73]. Similarly, genetic deletion of another member of the NF- $\mathrm{kB}$ family, the p50 subunit, a condition that is associated with increased p65-mediated transcription, correlates with significantly decreased hippocampal neurogenesis in adult mice [72]. On the other hand, we demonstrated that NF-KB -mediated transcription is involved in both proneurogenic and antidepressant effects of other clinically relevant drugs, such as $\alpha 2 \delta 1$ ligands pregabalin and gabapentin [79].

The fact that both induction and prevention of depressive-like behavior and ahNG may rely on activation of NF- $\mathrm{kB}$ signaling pathway is likely to reflect the complexity within that regulatory system. The NF-KB protein family is composed of several members, in addition to p65, which can combine to form dimers with different subunit composition which can be differentially activated and exert distinct, even opposite, functions through activation of specific sets of gene targets [87-91]. The p65 as well as other NF- $\mathrm{KB}$ subunits can undergo different posttranslational modifications in addition to acetylation, including ubiquitination, phosphorylation, sumoylation, nitrosylation, and methylation [92]. It is possible that specific combination of posttranslational changes within p65 may ultimately dictate distinct NF- $\mathrm{kB}$ mediated transcriptional programs associated with induction of depressive-like behavior or with antidepressant effects. In the future, it may be important to identify the full set of NF-KB gene targets activated in the hippocampus and prefrontal cortex in response to stress/LAC treatment, whose products may potentially represent novel biomarkers or targets in mood disorders.

Last but not least, we do not want to infer that NF- $\mathrm{kB}$ p65 acetylation and increased mGlu2 gene transcription represent the only mechanisms underlying LAC pharmacological effects. Recent literature data strongly support this idea. In the UCMS paradigm, LAC-mediated reversal of depressive-like behavior was shown to activate a PI3K/AKT/BDNF/VGF signaling pathway [93]. Using endogenously depressed FSL rats, it has been recently reported that oral administration of LAC results in antidepressant-like effects along with improved energy metabolism in the ventral dentate gyrus (vDG) [85]. A detailed transcriptome analysis of vDG identified several metabolic regulatory genes as potential key markers of LAC antidepressant responsiveness and, interestingly, also of predisposition to depressive-like behaviour. More specifically, mineralcorticoid receptor (MR) and leptin receptor (Lepr) transcripts appeared upregulated, whereas mGlu2 and NPY transcripts were downregulated in VDG of FSL rats. Such changes were rapidly corrected by LAC treatment in drug responsive animals [85]. LAC also corrected hyperinsulinemia and hyperglycemia in FSL rats [85].

Other literature data contribute to the concept of pleiotropicity of action for LAC antidepressant effects. It has been proposed that LAC may act as an antidepressant via increased levels of the glia-derived growth factor artemin [94]. Moreover, the drug can increase hippocampal levels of noradrenaline and serotonin, well established positive modulators of adult neurogenesis $[80,82,95]$. The possibility that the effects of LAC on synaptic energy state may contribute to its antidepressant effects has also been proposed [96]. Finally, regions other than hippocampus and prefrontal cortex may represent the target of LAC pharmacological activity. For example, medial amygdala stellate neurons have been suggested as a novel component in stress response, and LAC has been shown to promote structural plasticity in these cells [97]. 


\section{Therapeutic Implications of LAC Unique Pharmacological Profile}

Mood disorders are highly prevalent and disabling conditions. Despite a large number of clinically available drugs, as of today, nearly two-thirds of individuals do not achieve full symptomatic remission after treatment with conventional antidepressants [98]. In addition, in treatment responders several weeks $(2-6 \mathrm{w})$ of drug treatment are required to obtain clinical effects, a lag time which has considerable implications ranging from high suicide risk to reduced compliance [98]. Even when remission is achieved, the majority of individuals also suffer residual symptoms, including chronic pain and cognitive impairment, which further contribute to the disease burden. At present, one clinical study in dysthymic patients has proposed that LAC may be more rapid in its therapeutic effects than the selective serotonin reuptake inhibitor fluoxetine. This finding is preliminary, but it is quite interesting that in animal models, drug effects were also more rapid when compared to the tricyclic antidepressant chlorimipramine [51]. Future studies in larger and more heterogenous patient populations need to confirm this preliminary observation. The characteristic lag time in classical antidepressant effectiveness has given impulse to the search for novel therapeutics with more rapid effects. In such respect, the finding of ketamine as a rapid antidepressant in drug resistant patients has been a major breakthrough [99-101]. Unfortunately, the drug is characterized by adverse effects that limit its use [102]. Unlike ketamine, LAC has a high tolerability profile, and it is considered safe in humans [62]. In principle, this could allow its employment even in patient subpopulations who are very sensitive to the side effects associated with classical monoaminergic antidepressant drugs. LAC clinical studies were mainly performed in elderly patients. A recent meta-analysis confirmed that LAC is indeed more effective in older than in younger patients [61]. At present, no clear explanation is available for such a peculiarity of LAC. Although research efforts are required to confirm these findings, they suggest that LAC may represent a potential alternative to classical antidepressants. In particular, the elderly population and patients with comorbid medical conditions that make them vulnerable to adverse drug effects could represent an ideal subpopulation for LAC administration. In the future, it may also be interesting to assess whether LAC may produce antidepressant effects in subpopulations of drug-resistant patients.

LAC is currently marketed for treatment of neuropathic pain. Several studies, including double-blind placebo-controlled studies, have shown that LAC may represent a consistent therapeutic option for peripheral neuropathies [52,103]. As previously mentioned, LAC-mediated modulation of mGlu2 gene expression via NF- $\mathrm{kB}$ p65 acetylation has been proposed as a major contributor to its analgesic effects $[7,50,56,103]$. Recently, it has been shown that LAC, compared to other effective analgesic drugs, can also result in a very long-lasting analgesic effect in experimental models of both chronic inflammatory and neuropathic pain [53]. Once again, LAC long lasting effects were associated with an increase in mGlu2 receptor protein levels in the dorsal horns of spinal cord [53]. These observations have important clinical implications in view of the possibility that the drug might also reduce relapses in patients suffering from chronic pain. In light of the frequent comorbidity between depression and chronic pain [104], LAC exerting antidepressant and analgesic effects via common mechanisms (Figure 2) may represent an ideal treatment option.

In summary, for a long time there have been few drugs mechanistically distinct from classical monoaminergic antidepressants for treatment of mood disorder. LAC represents a next-generation antidepressant drug with novel mechanisms of action and high tolerability. Future investigations of the detailed cellular and molecular mechanisms underlying LAC effects may help in the development of potentially rapidly acting therapeutics and, in parallel, increase our current knowledge on the pathophysiology of depressive disorders. 


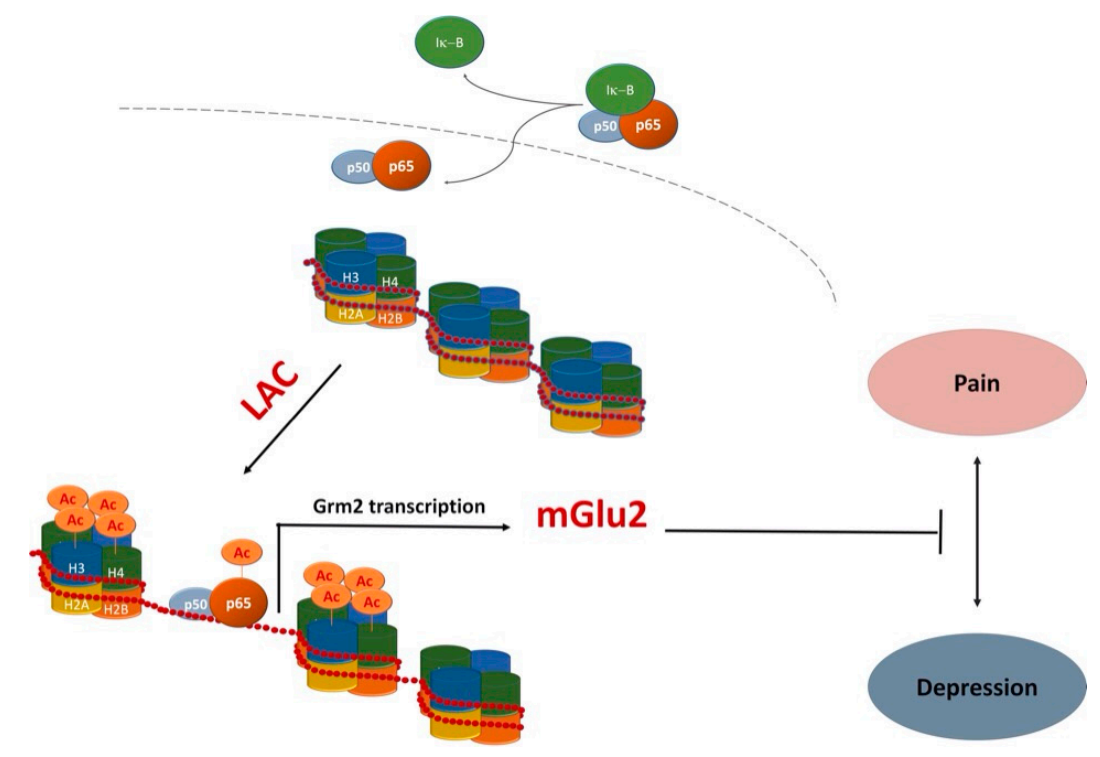

Figure 2. One potentially common mechanism underlying antidepressant and analgesic effects of LAC. LAC enhances $m G l u 2$ receptor (Grm2) gene transcription by acting as a donor of acetyl groups to NF-кB p65 and histones $\mathrm{H} 3$ and $\mathrm{H} 4[7,8,51,53,56]$.

Author Contributions: Both Santina Chiechio and Mariagrazia Grilli conceived, wrote, and revised the manuscript. Pier Luigi Canonico revised the manuscript.

Conflicts of Interest: The authors declare no conflict of interest.

$\begin{array}{ll}\text { Abbreviations } & \\ \text { ahNG } & \text { Adult Hippocampal Neurogenesis } \\ \text { AcetylCoA } & \text { Acetyl-Coenzyme A (acetyl-CoA) } \\ \text { ahNPC } & \text { Adult Hippocampal Neural Progenitor Cell } \\ \text { BDNF } & \text { Brain Derived Growth Factor } \\ \text { CACT } & \text { Carnitine/Acetylcarnitine Translocase } \\ \text { CAT } & \text { Carnitine Acetyltransferase } \\ \text { ChAT } & \text { Choline Acetyltransferase } \\ \text { FSL } & \text { Flinders Sensitive Line } \\ \text { FRL } & \text { Flinders Resistant Line } \\ \text { GABA } & \text { Gamma-aminobutyric Acid } \\ \text { HAT } & \text { Histone Acetyltransferase } \\ \text { HDAC } & \text { Histone Deacetylase } \\ \text { Lys } & \text { Lysine } \\ \text { i.c.v. } & \text { Intracerebroventricular } \\ \text { LAC } & \text { L-AcetylCarnitine } \\ \text { Lepr } & \text { Leptin receptor } \\ \text { MDD } & \text { Major Depressive Disorder } \\ \text { mGlu2 } & \text { Metabotropic Glutamate Receptor type-2 } \\ \text { NAc } & \text { Nucleus Accumbens } \\ \text { MR } & \text { Mineralcorticoid Receptor } \\ \text { NPC } & \text { Neural Progenitor Cell } \\ \text { NF- } \text { B } & \text { Nuclear Factor in the Kappa Light Chain Enhancer of B cells } \\ \text { OCTN2 } & \text { Organic Cation/Carnitine Transporter } \\ \text { RCT } & \text { Randomized Clinical Trials } \\ \text { UCMS } & \text { Unpredictable Chronic Mild Stress } \\ \end{array}$




\section{References}

1. Farrell, S.; Vogel, J.; Bieber, L.L. Entry of acetyl-L-carnitine into biosynthetic pathways. Biochim. Biophys. Acta 1986, 876, 175-177. [CrossRef]

2. Pettegrew, J.W.; Levine, J.; McClure, R.J. Acetyl-L-carnitine physical-chemical, metabolic, and therapeutic properties: Relevance for its mode of action in Alzheimer's disease and geriatric depression. Mol. Psychiatry 2000, 5, 616-632. [CrossRef] [PubMed]

3. Nałecz, K.A.; Miecz, D.; Berezowski, V.; Cecchelli, R. Carnitine: Transport and physiological functions in the brain. Mol. Asp. Med. 2004, 25, 551-567. [CrossRef] [PubMed]

4. Virmani, A.; Binienda, Z. Role of carnitine esters in brain neuropathology. Mol. Asp. Med. 2004, 25, 533-549. [CrossRef] [PubMed]

5. Calabrese, V.; Giuffrida Stella, A.M.; Calvani, M.; Butterfield, D.A. Acetylcarnitine and cellular stress response: Roles in nutritional redox homeostasis and regulation of longevity genes. J. Nutr. Biochem. 2006, 17, 73-88. [CrossRef] [PubMed]

6. Zanelli, S.A.; Solenski, N.J.; Rosenthal, R.E.; Fiskum, G. Mechanisms of ischemic neuroprotection by acetyl-L-carnitine. Ann. N. Y. Acad. Sci. 2005, 1053, 153-161. [CrossRef] [PubMed]

7. Chiechio, S.; Copani, A.; de Petris, L.; Morales, M.E.; Nicoletti, F.; Gereau, R.W., IV. Transcriptional regulation of metabotropic glutamate receptor $2 / 3$ expression by the NF-kappaB pathway in primary dorsal root ganglia neurons: A possible mechanism for the analgesic effect of L-acetylcarnitine. Mol. Pain 2006, 2, 20. [CrossRef] [PubMed]

8. Cuccurazzu, B.; Bortolotto, V.; Valente, M.M.; Ubezio, F.; Koverech, A.; Canonico, P.L.; Grilli, M. Upregulation of mGlu2 receptors via NF- $\mathrm{BB}$ p65 acetylation is involved in the proneurogenic and antidepressant effects of acetyl-L-carnitine. Neuropsychopharmacology 2013, 38, 2220-2230. [CrossRef] [PubMed]

9. Pettegrew, J.W.; Klunk, W.E.; Panchalingam, K.; Kanfer, J.N.; McClure, R.J. Clinical and neurochemical effects of acetyl-L-carnitine in Alzheimer's disease. Neurobiol. Aging 1995, 16, 1-4. [CrossRef]

10. Barrett, A.M. A 1-year controlled trial of acetyl-L-carnitine in early-onset AD. Neurology 2001, 56, 425. [CrossRef] [PubMed]

11. Thal, L.J.; Calvani, M.; Amato, A.; Carta, A. A 1-year controlled trial of acetyl-L-carnitine in early-onset AD. Neurology 2000, 55, 805-810. [CrossRef] [PubMed]

12. Montgomery, S.A.; Thal, L.J.; Amrein, R. Meta-analysis of double blind randomized controlled clinical trials of acetyl-L-carnitine versus placebo in the treatment of mild cognitive impairment and mild Alzheimer's disease. Int. Clin. Psychopharmacol. 2003, 18, 61-71. [CrossRef] [PubMed]

13. Puca, F.M.; Genco, S.; Specchio, L.M.; Brancasi, B.; D’Ursi, R.; Prudenzano, A.; Miccoli, A.; Scarcia, R.; Martino, R.; Savarese, M. Clinical pharmacodynamics of acetyl-L-carnitine in patients with Parkinson's disease. Int. J. Clin. Pharmacol. Res. 1990, 10, 139-143. [PubMed]

14. Goety, C.G.; Tanner, C.M.; Cohen, J.A.; Thelen, J.A.; Carroll, V.S.; Klawans, H.L.; Fariello, R.G. L-acetyl-carnitine in Huntington's disease: Double-blind placebo controlled crossover study of drug effects on movement disorder and dementia. Mov. Disord. 1990, 5, 263-265. [PubMed]

15. De Falco, F.A.; D'Angelo, E.; Grimaldi, G.; Scafuro, F.; Sachez, F.; Caruso, G. Effect of the chronic treatment with L-acetylcarnitine in Down's syndrome. Clin. Ter. 1994, 144, 123-127. [PubMed]

16. Bersani, G.; Meco, G.; Denaro, A.; Liberati, D.; Colletti, C.; Nicolai, R.; Bersani, F.S.; Koverech, A. L-Acetylcarnitine in dysthymic disorder in elderly patients: A double-blind, multicenter, controlled randomized study vs. fluoxetine. Eur. Neuropsychopharmacol. 2013, 23, 1219-1225. [CrossRef] [PubMed]

17. Zanardi, R.; Smeraldi, E. A double-blind, randomised, controlled clinical trial of acetyl-L-carnitine vs. amisulpride in the treatment of dysthymia. Eur. Neuropsychopharmacol. 2006, 16, 281-287. [CrossRef] [PubMed]

18. De Grandis, D.; Minardi, C. Acetyl-L-carnitine (levacecarnine) in the treatment of diabetic neuropathy. A long-term, randomised, double-blind, placebo-controlled study. Drugs $R$ D 2002, 3, 223-231. [CrossRef] [PubMed]

19. Sima, A.A.; Calvani, M.; Mehra, M.; Amato, A. Acetyl-L-Carnitine Study Group. Acetyl-L-carnitine improves pain, nerve regeneration, and vibratory perception in patients with chronic diabetic neuropathy: An analysis of two randomized placebo-controlled trials. Diabetes Care 2005, 28, 89-94. [CrossRef] [PubMed] 
20. Li, S.; Li, Q.; Li, Y.; Li, L.; Tian, H.; Sun, X. Acetyl-L-carnitine in the treatment of peripheral neuropathic pain: A systematic review and meta-analysis of randomized controlled trials. PLoS ONE 2015, 10, e0119479. [CrossRef]

21. Li, S.; Chen, X.; Li, Q.; Du, J.; Liu, Z.; Peng, Y.; Xu, M.; Li, Q.; Lei, M.; Wang, C.; et al. Effects of acetyl-L-carnitine and methylcobalamin for diabetic peripheral neuropathy: A multicenter, randomized, double-blind, controlled trial. J. Diabetes Investig. 2016, 7, 777-785. [CrossRef] [PubMed]

22. Osio, M.; Muscia, F.; Zampini, L.; Nascimbene, C.; Mailland, E.; Cargnel, A.; Mariani, C. Acetyl-L-carnitine in the treatment of painful antiretroviral toxic neuropathy in human immunodeficiency virus patients: An open label study. J. Peripher. Nerv. Syst. 2006, 11, 72-76. [CrossRef] [PubMed]

23. Curran, M.W.; Olson, J.; Morhart, M.; Sample, D.; Chan, K.M. Acetyl-L-carnitine (ALCAR) to enhance nerve regeneration in carpal tunnel syndrome: Study protocol for a randomized, placebo-controlled trial. Trials 2016, 17, 200. [CrossRef] [PubMed]

24. Leombruni, P.; Miniotti, M.; Colonna, F.; Sica, C.; Castelli, L.; Bruzzone, M.; Parisi, S.; Fusaro, E.; Sarzi-Puttini, P.; Atzeni, F.; et al. A randomised controlled trial comparing duloxetine and acetyl L-carnitine in fibromyalgic patients: Preliminary data. Clin. Exp. Rheumatol. 2015, 33, S82-S85. [PubMed]

25. Rossini, M.; di Munno, O.; Valentini, G.; Bianchi, G.; Biasi, G.; Cacace, E.; Malesci, D.; La Montagna, G.; Viapiana, O.; Adami, S. Double-blind, multicenter trial comparing acetyl L-carnitine with placebo in the treatment of fibromyalgia patients. Clin. Exp. Rheumatol. 2007, 25, 182-188. [PubMed]

26. Brunner, S.; Kramar, K.; Denhardt, D.T.; Hofbauer, R. Cloning and characterization of murine carnitine acetyltransferase: Evidence for a requirement during cell cycle progression. Biochem. J. 1997, 322, 403-410. [CrossRef] [PubMed]

27. Wu, D.; Govindasamy, L.; Lian, W.; Gu, Y.; Kukar, T.; Agbandje-McKenna, M.; McKenna, R. Structure of human carnitine acetyltransferase. Molecular basis for fatty acyl transfer. J. Biol. Chem. 2003, 278, 13159-13165. [CrossRef] [PubMed]

28. Ramsay, R.R.; Arduini, A. The carnitine acyltransferases and their role in modulating acyl-CoA pools. Arch. Biochem. Biophys. 1993, 302, 307-314. [CrossRef] [PubMed]

29. Ramsay, R.R.; Gandour, R.D.; van der Leij, F.R. Molecular enzymology of carnitine transfer and transport. Biochim. Biophys. Acta 2001, 1546, 21-43. [CrossRef]

30. Pande, S.V. A mitochondrial carnitine acylcarnitine translocase system. Proc. Natl. Acad. Sci. USA 1975, 72, 883-887. [CrossRef] [PubMed]

31. Indiveri, C.; Iacobazzi, V.; Tonazzi, A.; Giangregorio, N.; Infantino, V.; Convertini, P.; Console, L.; Palmieri, F. The mitochondrial carnitine/acylcarnitine carrier: Function, structure and physiopathology. Mol. Asp. Med. 2011, 32, 223-233. [CrossRef] [PubMed]

32. Tonazzi, A.; Giangregorio, N.; Console, L.; Indiveri, C. Mitochondrial carnitine/acylcarnitine translocase: Insights in structure/function relationships. Basis for drug therapy and side effects prediction. Mini Rev. Med. Chem. 2015, 15, 396-405. [CrossRef] [PubMed]

33. Madiraju, P.; Pande, S.V.; Prentki, M.; Madiraju, S.R. Mitochondrial acetylcarnitine provides acetyl groups for nuclear histone acetylation. Epigenetics 2009, 4, 399-403. [CrossRef] [PubMed]

34. Bresolin, N.; Freddo, L.; Vergani, L.; Angelini, C. Carnitine, carnitine acyltransferases, and rat brain function. Exp. Neurol. 1982, 78, 285-292. [CrossRef]

35. Shug, A.L.; Schmidt, M.J.; Golden, G.T.; Fariello, R.G. The distribution and role of carnitine in the mammalian brain. Life Sci. 1982, 31, 2869-2874. [CrossRef]

36. Parnetti, L.; Gaiti, A.; Mecocci, P.; Cadini, D.; Senin, U. Pharmacokinetics of IV and oral acetyl-L-carnitine in a multiple dose regimen in patients with senile dementia of Alzheimer type. Eur. J. Clin. Pharmacol. 1992, 42, 89-93. [CrossRef] [PubMed]

37. Kwon, O.S.; Chung, Y.B. HPLC determination and pharmacokinetics of endogenous acetyl-L-carnitine (ALC) in human volunteers orally administered a single dose of ALC. Arch. Pharm. Res. 2004, 27, 676-681. [CrossRef] [PubMed]

38. Miecz, D.; Januszewicz, E.; Czeredys, M.; Hinton, B.T.; Berezowski, V.; Cecchelli, R.; Nałecz, K.A. Localization of organic cation/carnitine transporter (OCTN2) in cells forming the blood-brain barrier. J. Neurochem. 2008, 104, 113-123. [CrossRef] [PubMed] 
39. Piovesan, P.; Pacifici, L.; Taglialatela, G.; Ramacci, M.T.; Angelucci, L. Acetyl-L-carnitine treatment increases choline acetyltransferase activity and NGF levels in the CNS of adult rats following total fimbria-fornix transection. Brain Res. 1994, 633, 77-82. [CrossRef]

40. Taglialatela, G.; Navarra, D.; Cruciani, R.; Ramacci, M.T.; Alemà, G.S.; Angelucci, L. Acetyl-L-carnitine treatment increases nerve growth factor levels and choline acetyltransferase activity in the central nervous system of aged rats. Exp. Gerontol. 1994, 29, 55-66. [CrossRef]

41. Foreman, P.J.; Perez-Polo, J.R.; Angelucci, L.; Ramacci, M.T.; Taglialatela, G. Effects of acetyl-L-carnitine treatment and stress exposure on the nerve growth factor receptor (p75NGFR) mRNA level in the central nervous system of aged rats. Prog. Neuropsychopharmacol. Biol. Psychiatry 1995, 19, 117-133. [CrossRef]

42. Sershen, H.; Harsing, L.G., Jr.; Banay-Schwartz, M.; Hashim, A.; Ramacci, M.T.; Lajtha, A. Effect of acetyl-L-carnitine on the dopaminergic system in aging brain. J. Neurosci. Res. 1991, 30, 555-559. [CrossRef] [PubMed]

43. Ando, S.; Tadenuma, T.; Tanaka, Y.; Fukui, F.; Kobayashi, S.; Ohashi, Y.; Kawabata, T. Enhancement of learning capacity and cholinergic synaptic function by carnitine in aging rats. J. Neurosci. Res. 2001, 66, 266-271. [CrossRef] [PubMed]

44. Imperato, A.; Ramacci, M.T.; Angelucci, L. Acetyl-L-carnitine enhances acetylcholine release in the striatum and hippocampus of awake freely moving rats. Neurosci. Lett. 1989, 107, 251-255. [CrossRef]

45. Fariello, R.G.; Ferraro, T.N.; Golden, G.T.; DeMattei, M. Systemic acetyl-L-carnitine elevates nigral levels of glutathione and GABA. Life Sci. 1988, 43, 289-292. [CrossRef]

46. Bähring, R.; Standhardt, H.; Martelli, E.A.; Grantyn, R. GABA-activated chloride currents of postnatal mouse retinal ganglion cells are blocked by acetylcholine and acetylcarnitine: How specific are ion channels in immature neurons? Eur. J. Neurosci. 1994, 6, 1089-1099. [CrossRef] [PubMed]

47. Dolezal, V.; Tucek, S. Utilization of citrate, acetylcarnitine, acetate, pyruvate and glucose for the synthesis of acetylcholine in rat brain slices. J. Neurochem. 1981, 36, 1323-1330. [CrossRef] [PubMed]

48. Calvani, M.; Carta, A.; Caruso, G.; Benedetti, N.; Iannuccelli, M. Action of acetyl-L-carnitine in neurodegeneration and Alzheimer's disease. Ann. N. Y. Acad. Sci. 1992, 663, 483-486. [CrossRef] [PubMed]

49. Szutowicz, A.; Bielarczyk, H.; Gul, S.; Zieliński, P.; Pawełczyk, T.; Tomaszewicz, M. Nerve growth factor and acetyl-L-carnitine evoked shifts in acetyl-CoA and cholinergic SN56 cell vulnerability to neurotoxic inputs. J. Neurosci. Res. 2005, 79, 185-192. [CrossRef] [PubMed]

50. Chiechio, S.; Copani, A.; Zammataro, M.; Battaglia, G.; Gereau, R.W., IV; Nicoletti, F. Transcriptional regulation of type-2 metabotropic glutamate receptors: An epigenetic path to novel treatments for chronic pain. Trends Pharmacol. Sci. 2010, 31, 153-160. [CrossRef] [PubMed]

51. Nasca, C.; Xenos, D.; Barone, Y.; Caruso, A.; Scaccianoce, S.; Matrisciano, F.; Battaglia, G.; Mathé, A.A.; Pittaluga, A.; Lionetto, L.; et al. L-acetylcarnitine causes rapid antidepressant effects through the epigenetic induction of mGlu2 receptors. Proc. Natl. Acad. Sci. USA 2013, 110, 4804-4809. [CrossRef] [PubMed]

52. Onofrj, M.; Ciccocioppo, F.; Varanese, S.; di Muzio, A.; Calvani, M.; Chiechio, S.; Osio, M.; Thomas, A. Acetyl-L-carnitine: From a biological curiosity to a drug for the peripheral nervous system and beyond. Expert Rev. Neurother. 2013, 13, 925-936. [CrossRef] [PubMed]

53. Notartomaso, S.; Mascio, G.; Bernabucci, M.; Zappulla, C.; Scarselli, P.; Cannella, M.; Imbriglio, T.; Gradini, R.; Battaglia, G.; Bruno, V.; et al. Analgesia induced by the epigenetic drug, L-acetylcarnitine, outlasts the end of treatment in mouse models of chronic inflammatory and neuropathic pain. Mol. Pain 2017, 13. [CrossRef] [PubMed]

54. Mai, A.; Massa, S.; Rotili, D.; Cerbara, I.; Valente, S.; Pezzi, R.; Simeoni, S.; Ragno, R. Histone deacetylation in epigenetics: An attractive target for anticancer therapy. Med. Res. Rev. 2005, 25, 261-309. [CrossRef] [PubMed]

55. Borrelli, E.; Nestler, E.J.; Allis, C.D.; Sassone-Corsi, P. Decoding the epigenetic language of neuronal plasticity. Neuron 2008, 60, 961-974. [CrossRef] [PubMed]

56. Chiechio, S.; Caricasole, A.; Barletta, E.; Storto, M.; Catania, M.V.; Copani, A.; Vertechy, M.; Nicolai, R.; Calvani, M.; Melchiorri, D.; et al. L-Acetylcarnitine induces analgesia by selectively up-regulating mGlu2 metabotropic glutamate receptors. Mol. Pharmacol. 2002, 61, 989-996. [CrossRef] [PubMed]

57. Zammataro, M.; Sortino, M.A.; Parenti, C.; Gereau, R.W., IV; Chiechio, S. HDAC and HAT inhibitors differently affect analgesia mediated by group II metabotropic glutamate receptors. Mol. Pain 2014, 10, 68. [CrossRef] [PubMed] 
58. Tempesta, E.; Casella, L.; Pirrongelli, C.; Janiri, L.; Calvani, M.; Ancona, L. L-acetylcarnitine in depressed elderly subjects. A cross-over study vs. placebo. Drugs Exp. Clin. Res. 1987, 13, 417-423. [PubMed]

59. Garzya, G.; Corallo, D.; Fiore, A.; Lecciso, G.; Petrelli, G.; Zotti, C. Evaluation of the effects of L-acetylcarnitine on senile patients suffering from depression. Drugs Exp. Clin. Res. 1990, 16, 101-106. [PubMed]

60. Bella, R.; Biondi, R.; Raffaele, R.; Pennisi, G. Effect of acetyl-L-carnitine on geriatric patients suffering from dysthymic disorders. Int. J. Clin. Pharmacol. Res. 1990, 10, 355-360. [PubMed]

61. Veronese, N.; Stubb, B.; Solmi, M.; Carvalho, A. Acetyl-L-Carnitine supplementation and the treatment of depressive symptoms: A systematic Review and Meta-analysis. Psychosom. Med. 2017. [CrossRef] [PubMed]

62. Meister, R.; von Wolff, A.; Mohr, H.; Härter, M.; Nestoriuc, Y.; Hölzel, L.; Kriston, L. Comparative safety of pharmacologic treatments for persistent depressive disorder: A systematic review and network meta-analysis. PLoS ONE 2016, 11, e0153380. [CrossRef] [PubMed]

63. Spalding, K.L.; Bergmann, O.; Alkass, K.; Bernard, S.; Salehpour, M.; Huttner, H.B.; Boström, E.; Westerlund, I.; Vial, C.; Buchholz, B.A.; et al. Dynamics of hippocampal neurogenesis in adult humans. Cell 2013, 153, 1219-1227. [CrossRef] [PubMed]

64. Santarelli, L.; Saxe, M.; Gross, C.; Surget, A.; Battaglia, F.; Dulawa, S.; Weisstaub, N.; Lee, J.; Duman, R.; Arancio, O.; et al. Requirement of hippocampal neurogenesis for the behavioral effects of antidepressants. Science 2003, 301, 805-809. [CrossRef] [PubMed]

65. David, D.J.; Samuels, B.A.; Rainer, Q.; Wang, J.W.; Marsteller, D.; Mendez, I.; Drew, M.; Craig, D.A.; Guiard, B.P.; Guilloux, J.P.; et al. Neurogenesis-dependent and -independent effects of fluoxetine in an animal model of anxiety/depression. Neuron 2009, 62, 479-493. [CrossRef] [PubMed]

66. Duman, R.S.; Nakagawa, S.; Malberg, J. Regulation of adult neurogenesis by antidepressant treatment. Neuropsychopharmacology 2001, 25, 836-844. [CrossRef]

67. Malberg, J.E. Implications of adult hippocampal neurogenesis in antidepressant action. J. Psychiatry Neurosci. 2004, 29, 196-205. [PubMed]

68. Dranovsky, A.; Hen, R. Hippocampal neurogenesis: Regulation by stress and antidepressants. Biol. Psychiatry 2006, 59, 1136-1143. [CrossRef] [PubMed]

69. Boldrini, M.; Santiago, A.N.; Hen, R.; Dwork, A.J.; Rosoklija, G.B.; Tamir, H.; Arango, V.; John Mann, J. Hippocampal granule neuron number and dentate gyrus volume in antidepressant-treated and untreated major depression. Neuropsychopharmacology 2013, 38, 1068-1077. [CrossRef] [PubMed]

70. Pittenger, C.; Duman, R.S. Stress, depression, and neuroplasticity: A convergence of mechanisms. Neuropsychopharmacology 2008, 33, 88-109. [CrossRef] [PubMed]

71. Eisch, A.J.; Petrik, D. Depression and hippocampal neurogenesis: A road to remission? Science 2012, 338, 72-75. [CrossRef] [PubMed]

72. Denis-Donini, S.; Dellarole, A.; Crociara, P.; Francese, M.T.; Bortolotto, V.; Quadrato, G.; Canonico, P.L.; Orsetti, M.; Ghi, P.; Memo, M.; et al. Impaired adult neurogenesis associated with short-term memory defects in NF-kappaB p50-deficient mice. J. Neurosci. 2008, 28, 3911-3919. [CrossRef] [PubMed]

73. Koo, J.W.; Russo, S.J.; Ferguson, D.; Nestler, E.J.; Duman, R.S. Nuclear factor-kappaB is a critical mediator of stress-impaired neurogenesis and depressive behavior. Proc. Natl. Acad. Sci. USA 2010, 107, 2669-2674. [CrossRef] [PubMed]

74. Valente, M.M.; Allen, M.; Bortolotto, V.; Lim, S.T.; Conant, K.; Grilli, M. The MMP-1/PAR-1 axis enhances proliferation and neuronal differentiation of adult hippocampal neural progenitor cells. Neural Plast. 2015, 2015. [CrossRef] [PubMed]

75. Nafez, S.; Oikawa, K.; Odero, G.L.; Sproule, M.; Ge, N.; Schapansky, J.; Abrenica, B.; Hatherell, A.; Cadonic, C.; Zhang, S.; et al. Early growth response 2 (Egr-2) expression is triggered by NF- $\mathrm{kB}$ activation. Mol. Cell. Neurosci. 2015, 64, 95-103. [CrossRef] [PubMed]

76. Kaltschmidt, B.; Kaltschmidt, C. NF-KappaB in long-term memory and structural plasticity in the adult mammalian brain. Front. Mol. Neurosci. 2015, 8, 69. [CrossRef] [PubMed]

77. Cvijetic, S.; Bortolotto, V.; Manfredi, M.; Ranzato, E.; Marengo, E.; Salem, R.; Canonico, P.L.; Grilli, M. Cell autonomous and noncell-autonomous role of NF- $\mathrm{BB}$ p50 in astrocyte-mediated fate specification of adult neural progenitor cells. Glia 2017, 65, 169-181. [CrossRef] [PubMed]

78. Bortolotto, V.; Cuccurazzu, B.; Canonico, P.L.; Grilli, M. NF-kB mediated regulation of adult hippocampal neurogenesis: Relevance to mood disorders and antidepressant activity. Biomed. Res. Int. 2014, 2014. [CrossRef] [PubMed] 
79. Valente, M.M.; Bortolotto, V.; Cuccurazzu, B.; Ubezio, F.; Meneghini, V.; Francese, M.T.; Canonico, P.L.; Grilli, M. $\alpha 2 \delta$ ligands act as positive modulators of adult hippocampal neurogenesis and prevent depression-like behavior induced by chronic restraint stress. Mol. Pharmacol. 2012, 82, 271-280. [CrossRef] [PubMed]

80. Meneghini, V.; Cuccurazzu, B.; Bortolotto, V.; Ramazzotti, V.; Ubezio, F.; Tzschentke, T.M.; Canonico, P.L.; Grilli, M. The noradrenergic component in tapentadol action counteracts $\mu$-opioid receptor-mediated adverse effects on adult neurogenesis. Mol. Pharmacol. 2014, 85, 658-670. [CrossRef] [PubMed]

81. Bortolotto, V.; Grilli, M. Every cloud has a silver lining: Proneurogenic effects of A $\beta$ oligomers and HMGB-1 via activation of the RAGE-NF-кB axis. CNS Neurol. Disord. Drug Targets 2016. [CrossRef]

82. Bortolotto, V.; Mancini, F.; Mangano, G.; Salem, R.; Xia, E.; del Grosso, E.; Bianchi, M.; Canonico, P.L.; Polenzani, L.; Grilli, M. Proneurogenic effects of trazodone in murine and human neural progenitor cells. ACS Chem. Neurosci. 2017, 8, 2027-2038. [CrossRef] [PubMed]

83. Reagan-Shaw, S.; Nihal, M.; Ahmad, N. Dose translation from animal to human studies revisited. FASEB J. 2008, 22, 659-661. [CrossRef] [PubMed]

84. Schaevitz, L.R.; Nicolai, R.; Lopez, C.M.; D’Iddio, S.; Iannoni, E.; Berger-Sweeney, J.E. Acetyl-L-carnitine improves behavior and dendritic morphology in a mouse model of Rett syndrome. PLoS ONE 2012, 7, e51586. [CrossRef] [PubMed]

85. Bigio, B.; Mathe, A.A.; Sousa, V.C.; Zelli, D.; Svenningsson, P.; McEwen, B.; Nasca, C. Epigenetics and energetics in ventral hippocampus mediate rapid antidepressant action: Implications for treatment resistance. Proc. Natl. Acad. Sci. USA 2016, 113, 7906-7911. [CrossRef] [PubMed]

86. Christoffel, D.J.; Golden, S.A.; Dumitriu, D.; Robison, A.J.; Janssen, W.G.; Ahn, H.F.; Krishnan, V.; Reyes, C.M.; Han, M.H.; Ables, J.L.; et al. IкB kinase regulates social defeat stress-induced synaptic and behavioral plasticity. J. Neurosci. 2011, 31, 314-321. [CrossRef] [PubMed]

87. Bortolotto, V.; Grilli, M. Opiate analgesics as negative modulators of adult hippocampal neurogenesis: Potential implications in clinical practice. Front. Pharmacol. 2017, 8, 254. [CrossRef] [PubMed]

88. Grilli, M. Chronic pain and adult hippocampal neurogenesis: Translational implications from preclinical studies. J. Pain Res. 2017, 10, 2281-2286. [CrossRef] [PubMed]

89. Grilli, M.; Chiu, J.J.; Lenardo, M.J. NF-kappaB and Rel: Participants in a multiform transcriptional regulatory system. Int. Rev. Cytol. 1993, 143, 1-62. [PubMed]

90. Grilli, M.; Pizzi, M.; Memo, M.; Spano, P.F. Neuroprotection by aspirin and sodium salicylate through blockade of NF-kappaB activation. Science 1996, 274, 1383-1385. [CrossRef] [PubMed]

91. Grilli, M.; Memo, M. Transcriptional pharmacology of neurodegenerative disorders: Novel venue towards neuroprotection against excitotoxicity? Mol. Psychiatry 1997, 2, 192-194. [CrossRef] [PubMed]

92. Perkins, N.D. Post-translational modifications regulating the activity and function of the nuclear factor kappa B pathway. Oncogene 2006, 25, 6717-6730. [CrossRef] [PubMed]

93. Wang, W.; Lu, Y.; Xue, Z.; Li, C.; Wang, C.; Zhao, X.; Zhang, J.; Wei, X.; Chen, X.; Cui, W.; et al. Rapid-acting antidepressant-like effects of acetyl-L-carnitine mediated by PI3K/AKT/BDNF/VGF signaling pathway in mice. Neuroscience 2015, 285, 281-291. [CrossRef] [PubMed]

94. Di Cesare Mannelli, L.; Vivoli, E.; Salvicchi, A.; Schiavone, N.; Koverech, A.; Messano, M.; Nicolai, R.; Benatti, P.; Bartolini, A.; Ghelardini, C. Antidepressant-like effect of artemin in mice: A mechanism for acetyl-L-carnitine activity on depression. Psychopharmacology 2011, 218, 347-356. [CrossRef] [PubMed]

95. Smeland, O.B.; Meisingset, T.W.; Borges, K.; Sonnewald, U. Chronic acetyl-L-carnitine alters brain energy metabolism and increases noradrenaline and serotonin content in healthy mice. Neurochem. Int. 2012, 61, 100-107. [CrossRef] [PubMed]

96. Ferrari, F.; Gorini, A.; Villa, R.F. Functional proteomics of synaptic plasma membrane ATP-ases of rat hippocampus: Effect of L-acetylcarnitine and relationships with Dementia and Depression pathophysiology. Eur. J. Pharmacol. 2015, 756, 67-74. [CrossRef] [PubMed]

97. Lau, T.; Bigio, B.; Zelli, D.; McEwen, B.S.; Nasca, C. Stress-induced structural plasticity of medial amygdala stellate neurons and rapid prevention by a candidate antidepressant. Mol. Psychiatry 2017, 22, 227-234. [CrossRef] [PubMed]

98. Rush, A.J.; Warden, D.; Wisniewski, S.R.; Fava, M.; Trivedi, M.H.; Gaynes, B.N.; Nierenberg, A.A. STAR*D: Revising conventional wisdom. CNS Drugs 2009, 23, 627-647. [CrossRef] [PubMed] 
99. Berman, R.M.; Cappiello, A.; Anand, A.; Oren, D.A.; Heninger, G.R.; Charney, D.S.; Krystal, J.H. Antidepressant effects of ketamine in depressed patients. Biol. Psychiatry 2000, 47, 351-354. [CrossRef]

100. Preskorn, S.H. Ketamine: The hopes and the hurdles. Biol. Psychiatry 2012, 72, 522-523. [CrossRef] [PubMed]

101. Singh, I.; Morgan, C.; Curran, V.; Nutt, D.; Schlag, A.; McShane, R. Ketamine treatment for depression: Opportunities for clinical innovation and ethical foresight. Lancet Psychiatry 2017, 4, 419-426. [CrossRef]

102. Short, B.; Fong, J.; Galvez, V.; Shelker, W.; Loo, C.K. Side-effects associated with ketamine use in depression: A systematic review. Lancet Psychiatry 2017. [CrossRef]

103. Chiechio, S. Modulation of chronic pain by metabotropic glutamate receptors. Adv. Pharmacol. 2016, 75, 63-89. [CrossRef] [PubMed]

104. Doan, L.; Manders, T.; Wang, J. Neuroplasticity underlying the comorbidity of pain and depression. Neural Plast. 2015, 2015. [CrossRef] [PubMed]

(C) 2017 by the authors. Licensee MDPI, Basel, Switzerland. This article is an open access article distributed under the terms and conditions of the Creative Commons Attribution (CC BY) license (http://creativecommons.org/licenses/by/4.0/). 